\title{
ANALISIS DAERAH PENANGKAPAN IKAN MADIDIHANG (Thunnus albacares) BERDASARKAN SUHU PERMUKAAN LAUT DAN SEBARAN KLOROFIL-A DI PERAIRAN PROVINSI ACEH
}

\author{
THE CATCH OF MADIDIHANG FISH (Thunnus albacares) FROM THE TECHNICAL \\ AND BIOLOGICAL ASPECTS USING TROLL LINE IN PALABUHAN RATU WATERS
}

\author{
Samsul Bahri' ${ }^{1}$, Domu Simbolon ${ }^{2}$, Mustaruddin ${ }^{3}$ \\ ${ }^{1}$ Program Studi Teknologi Perikanan Laut, Sekolah Pascasarjana \\ ${ }^{2}$ Departemen Pemanfaatan Sumberdaya Perikanan, \\ Fakultas Perikanan dan Ilmu Kelautan, Institut Pertanian Bogor \\ Korespondensi : samsul.tpl@gmail.com, domusimbolon@gmail.com, mustaruddin@gmail.com
}

\begin{abstract}
Yellowfin tuna (Thunnus albacares) is a superior fish resources are distributed in an area of the waters of the Aceh province. So far, yellowfin tuna fishermens have a problem in determining operational point of fish fishing ground. Determination of fish fishing ground can be estimated from water condition that is species habitat and usually described with oceanographic parameters. Sea surface temperature (SPL) and chlorophyll-a are an important oceanography to know the existence of yellowfin tuna and to analyze a potential fishing ground easier. Therefore, this research aimed to examine and analyze fish fishing ground of yellowfin tuna based on SPL parameter and chlorophyll-a distributions in the waters of Aceh province. The methods used in this study include data of yellowfin tuna catches in the waters of Aceh Province with purposive sampling, and the SPL and chlorophyll-a analyses using the Modis Aqua satellite image data that are processed with AcrGIS software. The results showed the SPL distributions in the waters of Aceh province were range from $26-34{ }^{\circ} \mathrm{C}$. The highest SPL was reached $34.74{ }^{\circ} \mathrm{C}$, occurs in February and the lowest SPL $26.19^{\circ} \mathrm{C}$, occurs in April. Analysis of chlorophyll-a distributions in the waters of Aceh province were range 0.01-3.7 $\mathrm{mg} / \mathrm{m}^{3}$. The highest of chlorophyll-a was $3.75 \mathrm{mg} / \mathrm{m}^{3}$ occur in August, while the lowest chlorophyll-a was $0.0120 \mathrm{mg} /$ $\mathrm{m}^{3}$ occur in July. Based on regression analysis, the relationship between the distributions of SPL and chlorophyll-a not significantly to the catch yellowfin tuna in the waters of Aceh province.
\end{abstract}

Keyword: Aceh waters, chlorophyll-a, satellite image data, sea surface temperature

\section{ABSTRAK}

Ikan tuna madidihang (Thunnus albacares) merupakan sumberdaya ikan unggulan yang tersebar di wilayah perairan Provinsi Aceh. Sejauh ini, para nelayan ikan tuna madidihang mengalami kendala dalam menentukan titik operasional daerah penangkapan ikan. Penentuan daerah penangkapan ikan dapat diduga dari kondisi perairan yang merupakan habitat dari suatu spesies dan biasanya digambarkan dengan parameter oseanografi. Suhu permukaan laut (SPL) dan klorofil-a merupakan parameter oseanografi yang penting untuk mengetahui keberadaan ikan tuna madidihang dan mempermudah dalam menganalisis daerah penangkapan ikan yang potensial. Oleh karena itu, penelitian ini bertujuan mengkaji dan menganalisis daerah penangkapan ikan tuna madidihang berdasarkan parameter SPL dan sebaran klorofil-a, di perairan Provinsi Aceh. Metode yang digunakan dalam penelitian ini antara lain pengambilan data hasil tangkapan ikan tuna madidihang di lapangan secara purposive sampling di perairan Provinsi Aceh, serta analisis SPL dan klorofil-a menggunakan data citra satelit Aqua Modis yang diolah dengan software ArCGIS. Hasil penelitian menunjukkan sebaran SPL di perairan Provinsi Aceh berkisar antara 26.19- $32.8^{\circ} \mathrm{C}$. Nilai kisaran SPL tertinggi mencapai $32.87{ }^{\circ} \mathrm{C}$ terjadi pada bulan Maret, serta SPL terendah $26.19^{\circ} \mathrm{C}$ terjadi pada bulan April. Analisis sebaran klorofil-a di perairan Provinsi Aceh berkisar antara $0.02-3.47 \mathrm{mg} / \mathrm{m}^{3}$. Nilai klorofil-a tertinggi $3.47 \mathrm{mg} / \mathrm{m}^{3}$ terjadi pada bulan Mei, sedangkan nilai klorofil-a terendah $0.02 \mathrm{mg} / \mathrm{m}^{3}$ terjadi pada bulan Mei. Produktivitas hasil tangkapan ikan tuna madidihang tertinggi (435 kg) dicapai pada nilai SPL $28{ }^{\circ} \mathrm{C}$ dan klorofil $0.44 \mathrm{mg} / \mathrm{m}^{3}$. Berdasarkan analisis regresi linier berganda, sebaran SPL dan klorofil-a tidak berpengaruh nyata terhadap hasil tangkapan ikan tuna madidihang di perairan Provinsi Aceh.

Kata kunci: data citra satelit, klorofil-a, perairan Aceh, SPL 


\section{PENDAHULUAN}

Sumberdaya tuna madidihang (Thunnus albacares) yang tersebar di wilayah perairan Provinsi Aceh merupakan sumberdaya yang bersifat oseanik. Madidihang merupakan salah satu sumberdaya ikan unggulan yang terdapat di Provinsi Aceh, sebagai ikan jenis pelagis besar. Penyebaran madidihang di suatu wilayah perairan terbagi ke dalam dua kelompok. Kelompok pertama yaitu penyebaran sumber daya madidihang secara horizontal atau berdasarkan letak geografi perairan. Kelompok kedua yaitu penyebaran madidihang secara vertikal atau menurut kedalaman wilayah perairan. Beberapa faktor yang mempengaruhi ruaya dan keberadaan ikan dalam suatu perairan disebabkan oleh kondisi lingkungan, seperti suhu permukaan laut dan kesuburan perairan. Distribusi ikan pelagis seperti madidihang dapat diprediksi melalui analisis parameter oseanografi perairan yang berkaitan dengan perubahan-perubahan suhu permukaan laut secara bulanan (Leavastu \& Hela 1970). Menurut Bahtiar et al. (2012) teknik penangkapan yang efektif dan efisien memerlukan pengetahuan mengenai tingkah laku ikan madidihang. Beberapa informasi tentang tingkah laku ikan madidihang meliputi sebaran suhu permukaan laut, klorofil-a, dan kedalaman perairan. Parameter oseanografi sangat berperan terhadap variabilitas hasil tangkapan ikan, seperti klorofil dan suhu permukaan laut yang berpengaruh bagi keberadaan sumberdaya ikan (Lumban Gaol et al. 2004). Klorofil-a diperlukan oleh fitoplankton yang berada pada lapisan cahaya (fotik) untuk proses fotosintesisnya (Adnan 2010). Fitoplankton tersebut memegang peranan penting sebagai sumber nutrisi bagi ikan madidihang.

Berdasarkan data stastistik perikanan pusat secara keseluruhan jumlah produksi tangkapan madidihang Provinsi Aceh pada tahun 2003 sampai 2010 mencapai 47.631 ton dengan nilai komersial mencapai Rp 615.795.188,00 (Dinas Perikanan dan Kelautan Provinsi Aceh 2015). Data statistik perikanan Provinsi Aceh menunjukkan penurunan hasil tangkapan tuna madidihang dari tahun 2003 hingga 2010. Hal ini mengindikasikan adanya perubahan daerah penangkapan ikan tuna madidihang yang disebabkan oleh faktor lingkungan laut. Salah satu faktor yang berkaitan dengan keberhasilan dalam usaha penangkapan ikan madidihang di wilayah perairan Provinsi Aceh adalah ketepatan waktu dalam menentukan daerah penangkapan (fishing ground) atau daerah penangkapan ikan (DPI) yang layak untuk dijadikan daerah penangkapan madidihang. Selama ini nelayan di Provinsi Aceh mengalami berbagai macam kendala dalam menentukan daerah penangkapan tuna madidihang yaitu dalam menentukan titik operasional penangkapan. Beberapa permasalahan yang sering dialami antara lain belum ada informasi yang lengkap tentang hubungan SPL dan sebaran klorofil-a, belum tersedianya data peta daerah penangkapan ikan tuna madidihang yang dapat dijadikan acuan oleh nelayan Aceh, serta umumnya nelayan melakukan operasi penangkapan pada wilayah perairan yang sama, sehingga jumlah hasil tangkapan setiap trip penangkapan tidak menentu. Penentuan daerah penangkapan ikan dapat didekati dengan mencari indikator-indikator oseanografi yang mempengaruhi daerah penangkapan ikan di suatu wilayah perairan (Muklis et al. 2009).

Adanya berbagai kendala tersebut di atas maka perlu kajian mengenai kondisi oseanografi perairan yang kaitannya dengan daerah penangkapan (fishing ground) tuna madidihang di wilayah perairan Provinsi Aceh. Parameter yang dianalisis antara lain jumlah produktivitas dan komposisi hasil tangkapan ikan madidihang di perairan Provinsi Aceh berdasarkan ukuran panjang, jumlahhasiltangkapan, daerah penangkapan dan waktu penangkapan, sebaran SPL, klorofil-a, hubungan antara sebaran SPL) dan klorofil-a terhadap hasil tangkapan madidihang, serta daerah penangkapan ikan (DPI) madidihang yang potensial di perairan Provinsi Aceh. Dengan demikian, hipotesis penelitian ini adalah parameter oseanografi seperti sebaran SPL dan klorofil-a dapat digunakan untuk megetahui kondisi perairan daerah penangkapan ikan tuna madidihang, serta mempunyai korelasi terhadap hasil tangkapan ikan madidihang dan dapat memprediksi daerah penangkapan potensial ikan madidihang. Dengan mempelajari parameter perairan tersebut, dapat diketahui pola penyebaran ikan madidihang di wilayah perairan yang berhubungan dengan dinamika daerah penangkapan, sehingga permasalahan yang dihadapi oleh nelayan di Provinsi Aceh tersebut dapat teratasi dan terbentuk peta daerah penangkapan.

Penelitian ini bertujuan mengkaji 
kondisi perairan yang kaitannya dengan daerah penangkapan ikan tuna madidihang pada bulan Januari hingga Agustus 2015, berdasarkan parameter oseanografi yaitu suhu permukaan laut dan klorofil-a, di perairan Provinsi Aceh. Selain itu, penelitian ini bertujuan untuk mengetahui hubungan antara suhu permukaan laut dan klorofil-a terhadap produktivitas ikan tuna madidihang.

\section{METODE PENELITIAN}

Penelitian ini dilakukan secara purposive sampling. Pengambilan data primer dan analisis data dilaksanakan pada bulan Januari hingga Agustus 2015 di perairan Pulau Rondo, Perairan Sabang, Pulau Aceh, dan Perairan Kepulauan Nikobar Hindia, dengan mengikuti kapal pancing dan kapal purse seine (Gambar 1).

Data primer penelitian ini meliputi data SPL, jumlah dan jenis hasil tangkapan, ukuran ikan madidihang, waktu dan lokasi penangkapan. Data primer diperoleh dari hasi pengukuran atau pengamatan faktafakta yang terjadi di lokasi penelitian ketika kegiatan operasi penangkapan ikan madidihang. Data sekunder penelitian ini meliputi produksi tangkapan ikan madidihang bulanan Januari-Agustus 2015, data upaya penangkapan (effort), citra satelit berupa suhu permukaan laut dan klorofil-a, serta informasi lain yang erat kaitanya dengan penelitian ini.

Data upaya penangkapan dari hasil tangkapan yang didapatkan selama penelitian digunakan untuk menghitung CPUE (Catch per Unit Effort). Formula yang digunakan untuk menghitung CPUE ini adalah (Lima et al. 2000, dalam Petrere et al. 2010):

$$
\text { CPUE }=\frac{\text { Catch }_{i}}{\text { Effort }_{i}}=1,2,3, \ldots, n
$$

Keterangan:

$$
\begin{aligned}
\text { CPUE }= & \text { Hasil tangkapan per-upaya } \\
& \text { penangkapan }(\mathrm{kg} / \text { trip) dalam } \\
& \text { bulan ke-i } \\
\text { Catch }_{i}= & \text { Hasil tangkapan }(\mathrm{kg}) \text { dalam bulan } \\
& \text { ke-i } \\
\text { Effort }_{i}= & \begin{array}{l}
\text { Upaya penangkapan }(\text { trip }) \text { dalam } \\
\text { bulan ke-i }
\end{array}
\end{aligned}
$$

Nilai CPUE kemudian diinterpolasi dalam bentuk peta prediksi daerah penangkapan ikan potensial berdasarkan kepada lokasi penangkapan. Dengan melihat produksi dan produktivitas hasil tangkapan dapat diketahui fluktuasi hasil tangkapan berdasarkan waktu (temporal) dan lokasi/ daerah penangkapan ikan (spasial).

Data SPL yang digunakan dalam penelitian ini adalah data citra satelit Aqua Modis yang bersih dari tutupan awan dan data yang diambil adalah level 3. Data citra SPL dan klorofil-a diperoleh dengan mengunduh dari http://oceancolor.gsfc. nasa.gov/. Analisis data sebaran SPL dan klorofil-a dilakukan menggunakan data citra satelit Aqua Modis (Muklis et al. 2009; Putra et al. 2012; Kurniawati et al. 2015), yang meliputi pemilihan data citra satelit level 3 dan citra satelit yang dipilih adalah citra bulanan pada Januari-Agustus 2015, pengolahan citra satelit menggunakan perangkat lunak SeaDAS 6.4 dengan sistem operasi linux system virtual, pemotongan citra satelit (cropping), serta anotasi citra satelit.

Algoritma yang digunakan untuk menghasilkan nilai distribusi suhu permukaan laut adalah sebagai berikut (Muklis et al. 2009; Putra et al. 2012; Kurniawati et al. 2015):

Modis_SST $=c 1+c 2 * T_{31}+c 3 * T_{31-32}+c 4 *(\operatorname{Sec}(0)-$ $1 * T_{31-32}$

T31, T32 = Brightness temperature dari kanal 31 dan 32

$E=$ Sudut Zenith satelit

$C 1, C 2, C 3$ dan $C 4=$ Konstanta yang dinilai

Algoritma OC3M adalah algoritma yang dipakai dalam pengolahan citra satelit Aqua Modis untuk menghasilkan konsentrasi klorofil-a (McClain \& Feldman 2004). Persamaan algoritma OC3M adalah sebagai berikut:

$$
\begin{gathered}
C a=100.283-2.75 R+1.457 R^{2}+0.659 R^{2}-1.403 R^{4}, \\
R=\log _{10} \frac{\operatorname{Rrs} 443>\operatorname{Rrs} 488}{\operatorname{Rrs} 551}
\end{gathered}
$$

Keterangan:

$\mathrm{Ca}=$ Konsentrasi klorofil-a $\left(\mathrm{mg} / \mathrm{m}^{3}\right)$

$R \quad=$ Rasio relektansi

Rrs $\quad=$ Remote sensing reflectace

Daerah penangkapan madidihang berdasarkan hasil analisis tangkapan mengacu pada Putro (2002). Untuk menentukan hubungan antara variabel SPL dan klorofil-a terhadap variabel hasil tangkapan madidihang, dilakukan analisis 
regresi linier berganda (Wallpole 1995), dengan menggunakan bantuan software SPSS 20 untuk menganalisis hubungan SPL dan klorofil-a baik secara bersama maupun secara individual (uji F dan uji t). Persamaan regresi yang digunakan sebagai berikut (Wallpole 1995):
Keterangan:

$\mathrm{Y}^{\prime}=$ Variabel tidak bebas (jumlah tangkapan) $\mathrm{X} 1$ dan $\mathrm{X} 2=$ Variabel bebas $(\mathrm{SPL}$ dan klorofil-a)

$\mathrm{a}=$ Konstanta (nilai Y' apabila X1, X2, .....Xn)

$\mathrm{b}=$ Koefisien regresi (nilai peningkatan atau penurunan)

$$
Y^{\prime}=a+b 1 X 1+b 2 X 2+\ldots \ldots+b n X n
$$

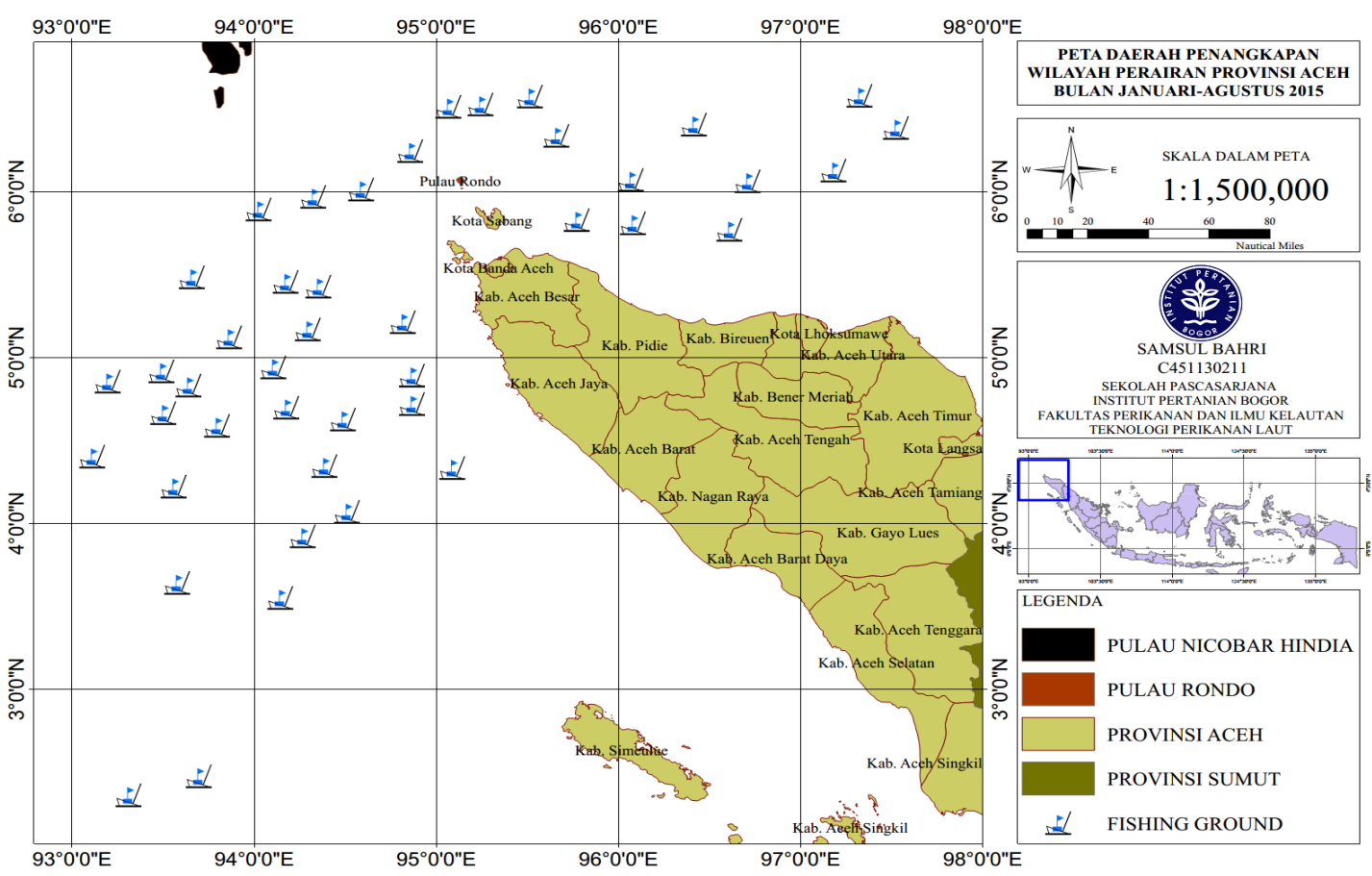

Gambar 1. Peta lokasi penelitian (perairan Provinsi Aceh)

\section{HASIL DAN PEMBAHASAN}

\section{Produksi ikan tuna madidihang (yellowfin tuna)}

Produksi ikan tuna madidihang dari bulan Januari-Agustus 2015 di perairan Provinsi Aceh cenderung fluktuatif. Berdasarkan data lapang, produksi tertinggi terjadi pada bulan Februari yaitu 3231 kg, dan terendah terjadi pada bulan Juni yaitu $1586 \mathrm{~kg}$ (Gambar 2).

Penyebaran secara spasial produksi ikan tuna madidihang di beberapa lokasi perairan menunjukkan pola yang bervariasi. Hasil tangkapan terendah terdapat di perairan Samudera Hindia dan Utara Aceh yaitu $823 \mathrm{~kg}$, kemudian juga terdapat di Pulau Rondo dan Sabang yaitu 1396 kg. Tangkapan tertinggi terdapat di perairan Pulau Aceh yaitu 4941 kg (Gambar 3).

\section{Produktivitas hasil tangkapan ikan madidihang (yellowfin tuna)}

Produktivitas hasil tangkapan ikan madidihang secara temporal disajikan pada (Gambar 4). Produktivitas tertinggi terdapat pada perairan Utara Aceh sebanyak $238 \mathrm{~kg} /$ DPI, kemudian disusul perairan Samudera Hindia dan Sabang sebanyak 200 kg/ trip, sedangkan produktivitas terendah terdapat di wilayah perairan Samudera Hindia dan Utara Aceh sebanyak $51 \mathrm{~kg} /$ trip. Produktivitas rata-rata hasil tangkapan madidihang yang terdapat di sembilan lokasi penangkapan berkisar $155 \mathrm{~kg} /$ trip. Berdasarkan nilai produktivitas rata-rata tersebut, maka daerah penangkapan ikan (DPI) memiliki produktivitas tinggi terdapat di Perairan, Utara Aceh, Samudera Hindia, Perairan Seumeulu dan Perairan Pulau Aceh. DPI yang memiliki produktivitas rendah terdapat di perairan Samudera Hindia dan 
Perairan Utara Aceh, Perairan Sabang dan Perairan Pulau Rondo (Gambar 5).

\section{Penyebaran suhu permukaan laut musim barat}

Suhu permukaan laut yang relatif panas terdapat di wilayah Perairan Pantai Barat yang berkisar $28^{\circ} \mathrm{C}-31^{\circ} \mathrm{C}$. Sedangkan sebaran suhu dingin yang berkisar antara $26{ }^{\circ} \mathrm{C}-27{ }^{\circ} \mathrm{C}$ terdapat di wilayah perairan Pantai Utara, Perairan Sabang, Perairan Pulau Rondo dan Samudera Hindia. Pada bulan Februari 2015, pola sebaran spasial suhu permukaan laut relatif sama dengan sebaran suhu permukaan laut pada bulan Januari 2015. Dominasi suhu panas terdapat di perairan Pantai Barat Aceh, yang meliputi Perairan Seumeulu, perairan Sabang dan perairan Pulau Aceh dengan kisaran suhu optimum $28{ }^{\circ} \mathrm{C}-31.5$ ${ }^{\circ} \mathrm{C}$. Sedangkan sebaran dominasi suhu dingin yang berkisar antara $25^{\circ} \mathrm{C}-27.5{ }^{\circ} \mathrm{C}$ terdapat di wilayah perairan Pantai Utara
Aceh, Perairan Sabang, Samudera Hindia dan Pulau Aceh bagian Barat.

Dominasi suhu tinggi pada bulan Maret 2015 berkisar $30{ }^{\circ} \mathrm{C}-32{ }^{\circ} \mathrm{C}$ terdapat di wilayah perairan Pantai Utara Aceh, Sabang, Pulau Rondo Samudera Hindia, Pulau Aceh, dan bagian utara Pulau Aceh. Penyebaran spasial suhu dominan dingin yang berkisar $26{ }^{\circ} \mathrm{C}-27{ }^{\circ} \mathrm{C}$ terdapat di wilayah perairan Simeule, Aceh Barat dan perairan Aceh Jaya. Konsentrasi suhu dominan panas berkisar $30{ }^{\circ} \mathrm{C}-31{ }^{\circ} \mathrm{C}$ yang tersebar di wilayah perairan Pantai Utara Aceh dan Pantai Barat Aceh, konsentrasi SPL dominan tinggi lebih terkonsetrasi pada wilayah pesisir pantai. Sedangkan sebaran SPL dominan dingin pada bulan April lebih cenderung terdapat di perairan lepas pantai, yang meliputi perairan Pulau Aceh, Pulau Rondo, perairan Semeulu dan Perairan Samudera Hindia dengan konsentrasi berkisar $25{ }^{\circ} \mathrm{C}-27.5{ }^{\circ} \mathrm{C}$, dan cenderung menyebar secara merata.

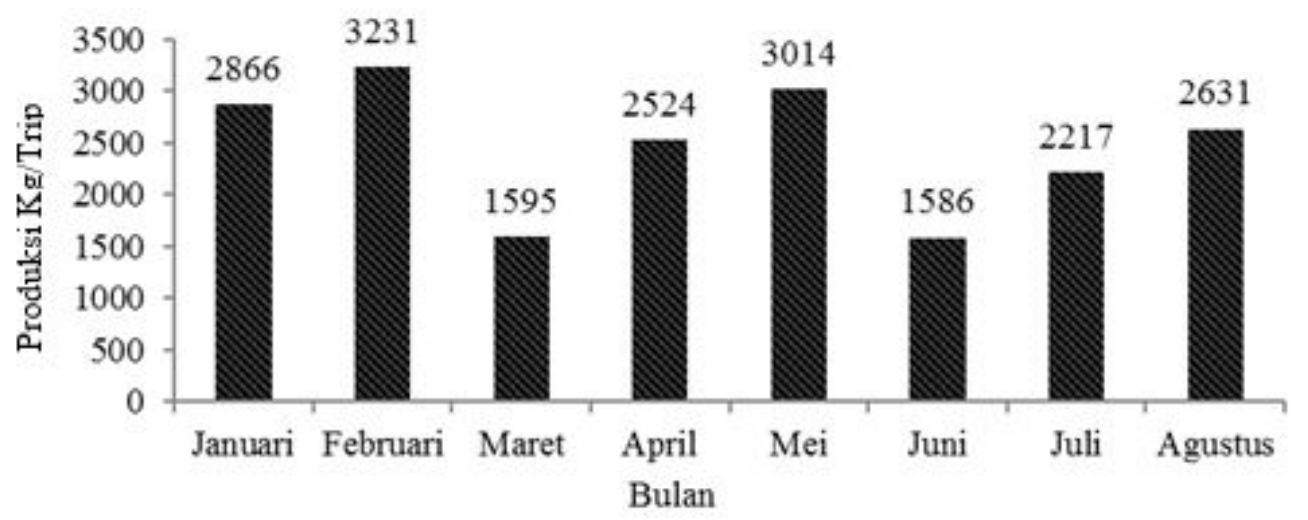

Gambar 2. Produksi hasil tangkapan ikan tuna madidihang pada bulan Januari-Agustus 2015, di perairan Provinsi Aceh

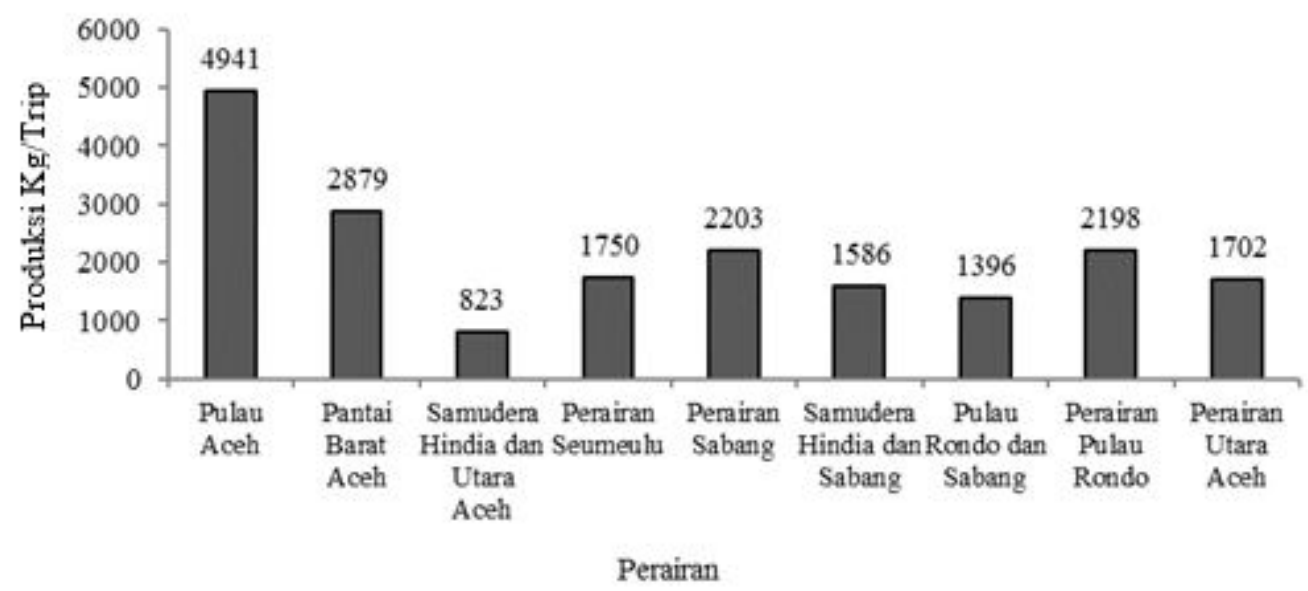

Gambar 3. Sebaran produksi ikan tuna madidihang pada bulan Januari- Agustus 2015, di perairan Provinsi Aceh 


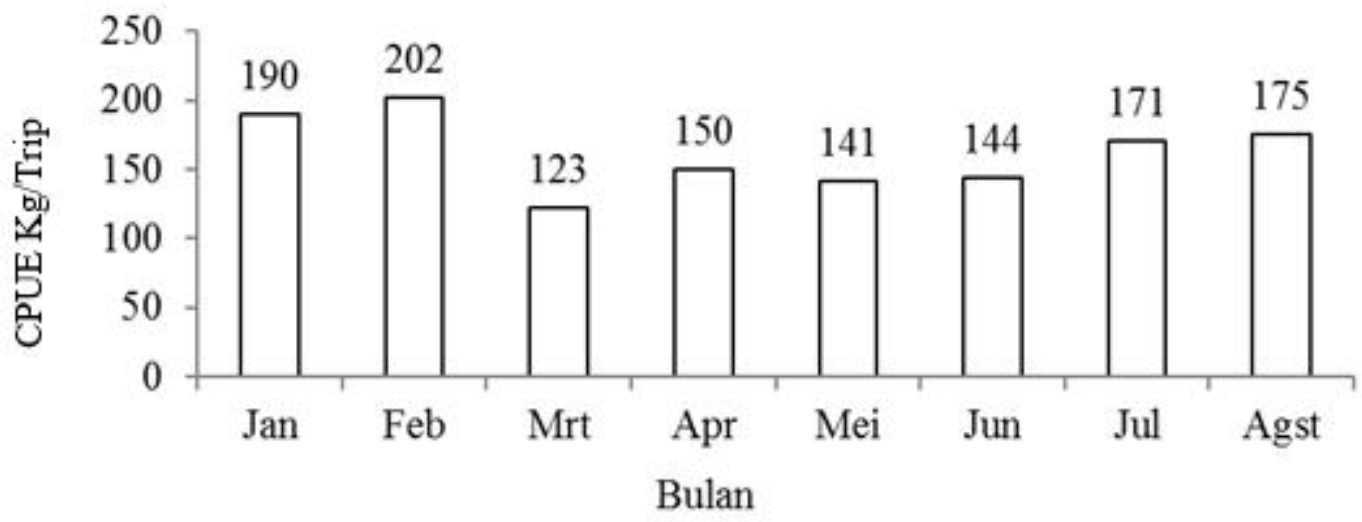

Gambar 4. Produktivitas CPUE ikan tuna madidihang secara temporal bulan Januari-Agustus 2015

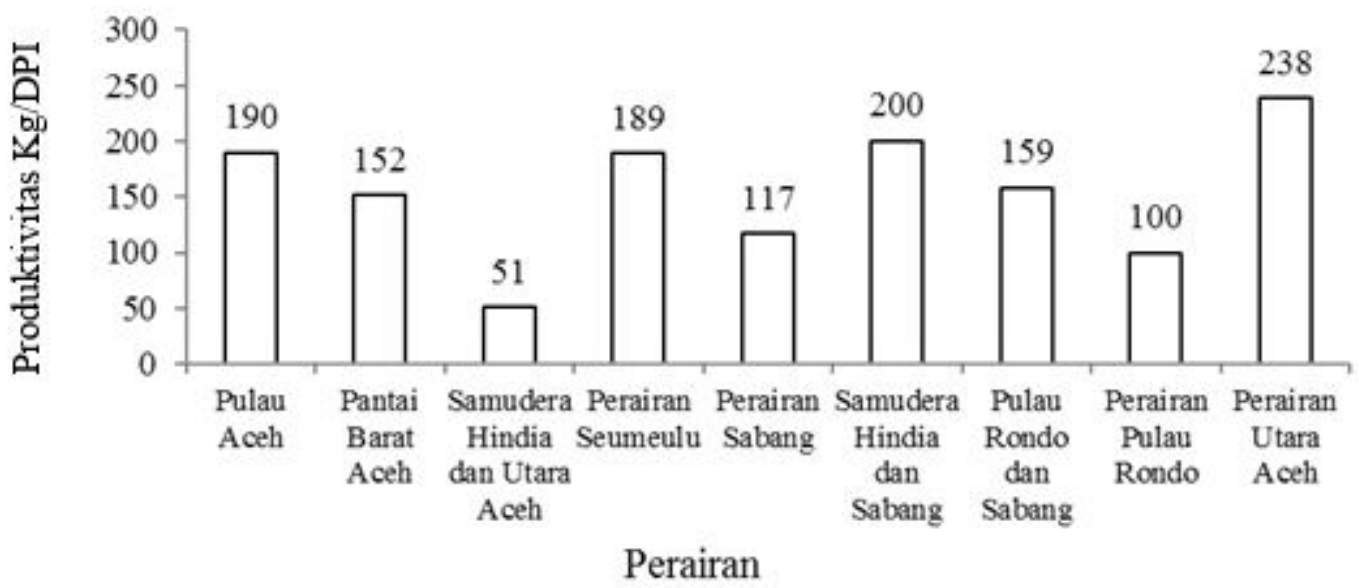

Gambar 5 Produktivitas CPUE ikan tuna madidihang berdasarkan spasial DPI pada bulan Januari-Agustus 2015

\section{Sebaran suhu permukaan laut musim peralihan}

Dominan suhu dingin pada bulan Mei 2015 berkisar $25{ }^{\circ} \mathrm{C}-27{ }^{\circ} \mathrm{C}$. terdapat di wilayah perairan Pantai Barat Aceh yang meliputi wilayah perairan Seumelu, Aceh Jaya, Pulau Aceh bagian barat dan meluas ke arah Samudera Hindia. Namun penyebaran dominan SPL tinggi terdapat di wilayah Perairan Utara Aceh dan menyebar secara merata ke arah perairan Sabang, Pulau Rondo dan Pulau Aceh dengan konsentrasi suhu berkisar $29{ }^{\circ} \mathrm{C}-31.5$ ${ }^{\circ} \mathrm{C}$. Dominansi suhu dingin berkisar 25.5 ${ }^{\circ} \mathrm{C}-27{ }^{\circ} \mathrm{C}$ tedapat di perairan Seumeulu, Pulau Aceh dan meyebar ke arah Samudera Hindia, sedangkan suhu panas berkisar 27 ${ }^{\circ} \mathrm{C}-31{ }^{\circ} \mathrm{C}$ terdapat di perairan Pantai Utara Aceh, dan Pantai Barat Aceh.

\section{Sebaran suhu permukaan laut musim timur}

Pola penyebaran SPL pada bulan Juli 2015 relatif sama dengan penyebaran SPL bulan Juni 2015. Akan tetapi dominansi suhu dingin di bagian Perairan Utara dan selatan lebih sempit penyebaranya. Khususnya di kawasan pesisir pantai yang cenderung meningkat. Sebaran spasial SPL pada bulan Agustus 2015 berbeda dengan bulan Juli dan Juni, walaupun sama-sama pada musim timur. Pada bulan Agustus ini dominansi suhu dingin $26^{\circ} \mathrm{C}-28^{\circ} \mathrm{C}$ terdapat di perairan Pantai Barat Aceh yang meliputi perairan Seumelu, Pulau Aceh, Pulau Rondo dan arah Selatan Pulau Seumeulu. Sebaliknya dominasi suhu panas $28^{\circ} \mathrm{C}-31$ ${ }^{\circ} \mathrm{C}$ terdapat di perairan Pantai Utara Aceh yang meliputi perairan Sabang, dan wilayah 
pesisir pantai Utara. Perbandingan sebaran spasial SPL pada bulan Januari-Agustus 2015 disajikan pada Tabel 1.

\section{Konsentrasi klorofil-a bulan Januari- Agustus 2015}

Kisaran klorofil-a berkisar 0.02-3.47 $\mathrm{mg} / \mathrm{m}^{3}$ dengan rata-rata $0.13-0.32 \mathrm{mg} /$ $\mathrm{m}^{3}$. Pada bagian utara dan selatan Provinsi Aceh, kandungan klorofil-a relatif lebih tinggi dibandingkan dengan perairan bagian barat Aceh. Kandungan klorofil-a pada bulan Februari 2015, di bagian utara juga masih tetap tinggi, seperti halnya dengan bulan Januari. Pada bulan Maret 2015, kandungan klorofil-a di seluruh zona pantai Provinsi Aceh relatif tinggi berkisar 0.03-3.05 $\mathrm{mg} / \mathrm{m}^{3}$, dibandingkan dengan zona lepas pantai. Khususnya perairan Bagian Utara Provinsi Aceh kandungan klorofil-a yang tinggi menyebar melalui dari zona pantai hingga ke arah lepas pantai. Peningkatan konsentrasi klorofil-a ada kaitannya dengan fenomena upwelling di perairan tersebut (Nurani et al. 2014). Perbandingan sebaran spasial kandungan klorofil-a pada bulan Januari-Agustus 2015 disajikan pada Tabel 2.

Kandungan klorofil-a pada bulan April 2015, hanya terdapat pada areal yang sempit berada pada kawasan perairan pantai berkisar $0.03 \mathrm{mg} / \mathrm{m}^{3}-2.78 \mathrm{mg} / \mathrm{m}^{3}$. Bulan Mei 2015, pola sebaran klorofil-a kembali menunjukkan pola yang relatif mirip dengan sebaran spasial pada bulan Maret 2015. Memasuki musim timur pada bulan Juni 2015, kandungan klorofil-a di perairan Provinsi Aceh relatif rendah. Kandungan klorofila-a tinggi hanya ditemukan pada areal yang sempit di kawasan pantai. Pola sebaran klorofil-a bulan Juli 2015 kawasan perairan yang memiliki klorofil-a tinggi lebih luas di bandingkan dengan Juni 2015. Pola sebaran spasial klorofil-a pada bulan Agustus 2015, klorofil-a tidak jauh berbeda dengan bulan Juli.

Tabel 1. Perbandingan sebaran SPL spasial di Perairan Provinsi Aceh periode bulan Januari- Agustus 2015

\begin{tabular}{llcccccccc}
\hline No & $\begin{array}{c}\text { Parameter } \\
\text { Oseanografi } \\
\text { SPL }\end{array}$ & Jan & Feb & Maret & April & Mei & Juni & Juli & Agustus \\
\hline 1 & Kisaran SPL & $27.6-$ & $27.6-$ & $28.5-$ & $26.19-$ & $27.6-$ & $27.8-$ & $26.9-$ & \\
& & 31.95 & 31.6 & 32.8 & 32.6 & 32.5 & 32.2 & 32.04 & $26.2-31.9$ \\
2 & Rata-rata SPL & 27.64 & 29.85 & 30.60 & 30.58 & 31.21 & 31.21 & 30.40 & 29.91 \\
3 & SPL Rendah & 27.64 & 27.98 & 28.57 & 26.19 & 27.61 & 27.81 & 26.98 & 26.27 \\
4 & SPLTinggi & 31.95 & 31.67 & 32.87 & 32.64 & 32.56 & 32.20 & 32.04 & 31.95 \\
5 & Nilai Varian & 0.37 & 0.59 & 0.43 & 0.43 & 0.50 & 0.22 & 0.26 & 0.41 \\
6 & Simpangan & & & & & & & & \\
& baku & 0.61 & 0.77 & 0.66 & 0.66 & 0.71 & 0.47 & 0.51 & 0.64 \\
\hline
\end{tabular}

Tabel 2. Perbandingan sebaran spasial kandungan klorofil-a di Perairan Provinsi Aceh periode bulan Januari- Agustus 2015

\begin{tabular}{|c|c|c|c|c|c|c|c|c|c|}
\hline No & $\begin{array}{c}\text { Parameter } \\
\text { Oseanografi } \\
\text { Klorofil-a }\end{array}$ & Jan & Feb & Maret & April & Mei & Juni & Juli & Agustus \\
\hline 1 & $\begin{array}{l}\text { Kisaran } \\
\text { Klorofil-a }\end{array}$ & $\begin{array}{l}0.04- \\
2.28\end{array}$ & $\begin{array}{l}0.03- \\
2.61\end{array}$ & $\begin{array}{l}0.03- \\
3.05\end{array}$ & $\begin{array}{l}0.03- \\
2.78\end{array}$ & $\begin{array}{l}0.02- \\
3.47\end{array}$ & $\begin{array}{l}0.07- \\
2.163\end{array}$ & $\begin{array}{l}0.05- \\
3.04\end{array}$ & $0.04-2.92$ \\
\hline 2 & $\begin{array}{l}\text { Rata-rata } \\
\text { Klorofil-a }\end{array}$ & 0.32 & 0.19 & 0.15 & 0.13 & 0.15 & 0.16 & 0.14 & 0.23 \\
\hline 3 & $\begin{array}{l}\text { Klorofil-a } \\
\text { Rendah }\end{array}$ & 0.11 & 0.03 & 0.03 & 0.03 & 0.02 & 0.07 & 0.05 & 0.04 \\
\hline 4 & Klorofi-a Tinggi & 2.28 & 2.61 & 3.05 & 2.79 & 3.47 & 2.16 & 3.05 & 2.92 \\
\hline 5 & Nilai Varian & 0.08 & 0.02 & 0.02 & 0.03 & 0.04 & 0.015 & 0.04 & 0.08 \\
\hline 6 & $\begin{array}{l}\text { Simpangan } \\
\text { baku }\end{array}$ & 0.28 & 0.14 & 0.14 & 0.18 & 0.20 & 0.12 & 0.20 & 0.28 \\
\hline
\end{tabular}




\section{Analisis sebaran SPL dan klorofil-a terhadap produksi terhadap produktivitas ikan madidihang}

Hubungan sebaran SPL dan sebaran klorofil-a terhadap produksi hasil tangkapan ikan madidihang pada bulan JanuariAgustus 2015 di Wilayah perairan Provinsi Aceh.

Hubungan kondisi oseanografi (SPL dan klorofil-a) dengan hasil tangkapan ikan tuna dianalisis menggunakan analisis regresi linier berganda dengan hasil tangkapan sebagai variabel tidak bebas (dependent), SPL dan klorofil-a dijadikan sebagai variabel bebas (independent). Analisis varians (uji F) digunakan untuk melihat pengaruh SPL dan klorofil-a secara bersama-sama terhadap hasil tangkapan ikan tuna madidihang (Tabel 3).

Tabel 3 menunjukkan bahwa nilai signifikansi yang diperoleh 0.388 lebih dari a (0.05) dengan Fhit $=0.954(<\mathrm{Ftab}(0.05)=$ 3.172). Hal ini menunjukkan bahwa secara bersama-sama SPL dan klorofil-a tidak berpengaruh nyata terhadap hasil tangkapan ikan tuna madidihang.

Nilai koefisien korelasi untuk mengetahui besarnya proporsi variabel tidak bebas terhadap variabel bebas yang diperoleh pada penelitian ini adalah 0.127. Hal ini berarti hubungan antara hasil tangkapan ikan tuna dengan parameter SPL dan klorofil-a sebesar 12.7\%. Koefisien determinasi (R2) adalah sebesar 0.016, artinya $1.6 \%$ pengaruh terhadap hasil tangkapan disebabkan oleh SPL dan klorofil-a, serta 98.4\% dipengaruhi oleh faktor lain.

Uji $t$ digunakan untuk melihat pengaruh faktor oseanografi terhadap hasil tangkapan ikan tuna madidihang secara individual. Parameter oseanografi yaitu SPL dan klorofil-a sebagai variabel bebas (X) dan hasil tangkapan sebagai variabel tidak bebas (Y). Nilai signifikansi SPL dan klorofil-a (Tabel 4) keduanya lebih besar dari a (0.05) dengan nilai sig. SPL 0.320 dan klorofil-a 0.334. Dengan demikian hasil tersebut menunjukkan bahwa secara individual kedua parameter oseanografi tersebut tidak berpengaruh nyata terhadap hasil tangkapan ikan tuna madidihang di perairan Provinsi Aceh.

Menurut Gradieff (2003), hubungan yang signifikan antara SPL dan hasil tangkapan ikan madidihang tuna diduga disebabkan karena pada umumnya ikan tuna merupakan predator yang selalu berada di lapisan permukaan pada siang hari untuk berburu mangsanya. Nilai kisaran SPL yang disukai oleh ikan yellowfin tuna yaitu antara $18-31{ }^{\circ} \mathrm{C}$ (FAO 2003). Akan tetapi, berdasarkan hasil analisis regresi pada penelitian ini, dapat terlihat bahwa nilai slope menunjukkan negatif, sehingga dapat dinyatakan bahwa faktor SPL dan klorofil-a pada penelitian ini keduanya tidak berpengaruh positif terhadap jumlah hasil tangkapan ikan tuna madidihang di Perairan Provinsi Aceh. Hal ini dapat disebabkan oleh nilai rata-rata SPL yang ditunjukkan pada penelitian ini cukup tinggi yaitu antara 29.7-31.2 ${ }^{\circ} \mathrm{C}$. Sedangkan jika dilihat dari faktor klorofil-a, Loukos et al. (2003) menyatakan bahwa fitoplankton bukan merupakan makanan alami tuna, tetapi sebagai rantai dasar makanan. Selain itu, menurut Girsang (2008) dalam Mujib et al. (2013) menyatakan bahwa konsentrasi klorofil-a yang terdapat di perairan tidak langsung mempengaruhi jumlah ikan yang berada pada daerah tersebut. Terdapat lag atau waktu bagi konsentrasi klorofil-a yang terdapat di wilayah perairan yang terlebih dahulu dimakan oleh struktur organisme herbivora, seperti zooplankton atau crustacean kecil dan selanjutnya dimakan oleh tingkat trofik di atasnya. Hal tersebut diduga menyebabkan faktor klorofil-a tidak berpengaruh nyata terhadap hasil tangkapan ikan tuna madidihang di perairan Provinsi Aceh, karena nilai rata-rata klorofil-a yang hanya sekitar $0.31 \mathrm{mg} / \mathrm{m}^{3}$. Berdasarkan penelitian Tangke et al. (2015), hasil analisis statistik antara parameter SPL dan klorofil-a menunjukkan secara bersamasama berpengaruh nyata, sedangkan secara individu SPL tidak berpengaruh nyata terhadap hasil tangkapan yellowfin tuna di Laut Halmahera bagian selatan. 
Tabel 3. Hasil uji F hasil tangkapan ikan tuna dengan SPL dan klorofil-a

\begin{tabular}{lrcccc}
\hline \multicolumn{1}{c}{ Model } & Sum of squares & Df & Mean square & F & Sig. \\
\hline Regression & 9077.877 & 2 & 4538.938 & .954 & $.388^{\mathrm{b}}$ \\
Residual & 556627.990 & 117 & 4757.504 & & \\
Total & 565705.867 & 119 & & & \\
\hline
\end{tabular}

a. Dependent variable: catch

b. Predictors: (constant), klorofil-a, SPL

Tabel 4 Hasil uji t hasil tangkapan ikan tuna dengan SPL dan klorofil-a

\begin{tabular}{|c|c|c|c|c|c|}
\hline \multirow[t]{2}{*}{ Model } & \multicolumn{2}{|c|}{$\begin{array}{c}\text { Unstandardized } \\
\text { coefficients }\end{array}$} & \multirow{2}{*}{$\begin{array}{r}\begin{array}{l}\text { Standardized } \\
\text { coefficients }\end{array} \\
\text { beta }\end{array}$} & \multirow[t]{2}{*}{$\mathbf{T}$} & \multirow[t]{2}{*}{ Sig. } \\
\hline & B & Std. error & & & \\
\hline (Constant) & 317.099 & 147.034 & & 2.157 & .033 \\
\hline$S P L$ & -5.328 & 5.337 & -.092 & -.998 & .320 \\
\hline Klorofil-a & -15.582 & 16.056 & -.089 & -.970 & .334 \\
\hline
\end{tabular}

a. Dependent variable: catch

\section{KESIMPULAN DAN SARAN}

\section{Kesimpulan}

Sebaran SPL di perairan Provinsi Aceh berkisar antara $26.19-31.95^{\circ} \mathrm{C}$. Nilai kisaran SPL tertinggi mencapai $32.87{ }^{\circ} \mathrm{C}$ terjadi pada bulan Maret, serta SPL terendah 26.19 ${ }^{\circ} \mathrm{C}$ terjadi pada bulan April. Analisis sebaran klorofil-a di perairan Provinsi Aceh berkisar antara $0.02-3.47 \mathrm{mg} / \mathrm{m}^{3}$. Nilai klorofil-a tertinggi $3.47 \mathrm{mg} / \mathrm{m}^{3}$ terjadi pada bulan Mei, sedangkan nilai klorofil-a terendah 0.02 $\mathrm{mg} / \mathrm{m}^{3}$ terjadi pada bulan Mei.

Berdasarkan nilai produktivitas ratarata, maka daerah penangkapan ikan (DPI) memiliki produktivitas tinggi terdapat di perairan, Utara Aceh, Samudera Hindia, Perairan Seumeulu dan Perairan Pulau Aceh. Produktivitas hasil tangkapan ikan tuna madidihang tertinggi (435 kg) dicapai pada nilai SPL $28{ }^{\circ} \mathrm{C}$ dan klorofil $0.44 \mathrm{mg} /$ $\mathrm{m}^{3}$. Hubungan antara hasil tangkapan ikan tuna dengan parameter SPL dan klorofil-a sebesar $12.7 \%$, dengan koefisien determinasinya (R2) sebesar 0.016, artinya hanya sebesar $1.6 \%$ pengaruh terhadap hasil tangkapan disebabkan oleh SPL dan klorofil-a, sedangkan 98.4\% diduga dipengaruhi oleh faktor lain.

\section{Saran}

Untuk penelitian selanjutnya, perlu dilakukan peningkatan upaya penangkapan hanya pada daerah yang potensial, pengumpulan data parameter oseanografi lainnya seperti salinitas, kecepatan arus dan lainnya, yang memungkinkan memberikan pengaruh terhadap kehidupan ikan tuna madidihang dan hasil tangkapan pada seluruh musim penangkapan.

\section{UCAPAN TERIMA KASIH}

Ucapan terima kasih penulis sampaikan kepada Dinas Kelautan dan Perikanan Provinsi Aceh atas ijin penelitian yang diberikan di perairan Provinsi Aceh. Penulis juga sampaikan terima kasih kepada Departemen Pemanfaatan Sumberdaya Perikanan FPIK IPB, atas fasilitas laboratorium penelitian yang telah disediakan.

\section{DAFTAR PUSTAKA}

Adnan. 2010. Analisis suhu permukaan laut dan klorofil data indaraja berhubungannya dengan hasil tangkapan ikan tongkol (Euthynnus affinis) di Perairan Kalimantan Timur. J PSP FPIK Unpatti. 1:1-12.

Bahtiar A, Abram Barata DN. 2012. Sebaran ikan tuna berdasarkan suhu dan kedalaman di Samudera Hindia. J Ilmu Kelautan. 16:165-170.

Dinas Perikanan dan Kelautan Provinsi Aceh. 2015. Laporan Tahunan 2015. Aceh.

[FAO] Food and Agriculture Organization. 2003. FAO Species Catalogue Vol.2 Scombrids of The World An Annotated 
and Ilustrated Catalogue of Tunas, Mackerel, Bonitas, and Related Species Known to Date. Rome: United Nation.

Gradieff S. 2003. Yellowfin tuna. http:// www.flmnh.ufl.edu. [diakses 31 Mei 2016].

Kurniawati F, Sanjoto TB, Juhadi. 2015. Pendugaan zona potensi penangkapan ikan pelagis kecil di perairan laut Jawa pada musim barat dan musim timur dengan menggunakan citra aqua modis. Geo Image 4:9-19. ISSN 2252-6285.

Leavastu T, Hela. 1970. Fisheries Oceonography and Ecology. England: Fishing New.

Lima AC, Freitas CEC, Abuabara MA, Petrere M, Batista VS. 2000. On the standardization of the fishing effort. Acta Amazonica 30:167-169.

Loukus HP, Monfry, Lehodey. 2003. Potensial Change in Skipjack Tuna (Katsuwonus pelamis) Habitat from a Global Warming. Oceanography. Blackwell Publishing.

Lumban Gaol J, Wudianto BP, Pasaribu D, Manurung, Endriani R. 2004. The fluctuation of chlorophyll-a concentration derived from satellite imagery and catch of oily sardine (Sardinella lemuru) in Bali strait. Int $\mathrm{J}$ Remote Sensing Earth Sci. 1:24-30.

McClain C, Feldman G. 2004. MODIS/ Aqua Evaluation. NASA Ocean Color Research Team Meeting. April 1416, 2004. Washington, DC. Retrieved October 3, 2005. http//oceancolor. gsfc.nasa.gov/DOCS/ScienceTea.

Mujib Z, Boesono H, Aristi DPF. 2013. Pemetaan sebaran ikan tongkol (Euthynnus sp.) dengan data klorofil-a citra modis pada alat tangkap paying (danish-seine) di perairan teluk
Pelabuhan Ratu, Sukabumi, Jawa Barat. J Fish Res Utiliz Man Technol. 2: 150-160.

Muklis, GaolJL, Simbolon D. 2009. Pemetaan daerah potensial penangkapan ikan cakalang (Katsuwonus pelamis) dan tongkol (Euthynnus affinis) di perairan utara Nanggroe Aceh Darussalam. E- J Ilmu Teknologi Kelautan Tropis $1: 24-32$.

Nurani TW, Wisudo SH, Wahyuningrum PI, Arhatin RE. 2014. Model pengembangan rumpon sebagai alat bantu dalam pemanfaatan sumber daya ikan tuna secara berkelanjutan. J Ilmu Pertanian Indonesia 19:57-65. ISSN 0853-4217.

Petrere JM, Giacomini HC, De Marco JP. 2010. Catch-per-unit-effort: which estimator is best?. Braz J Biol. 70:483491.

Putra et al. 2012. Hubungan konsentrasi klorofil-a dan suhu permukaan laut dengan hasil tangkapan ikan pelagis utama di perairan laut Jawa dari citra satelit modis. J Teknologi Perikanan Kelautan 3:1-10. ISSN 2087-4871.

Putro SME. 2002. Studi daerah penangkapan ikan (fishing ground) kapal purse seine di perairan utara laut Jawa [laporan ilmiah]. Semarang: Jurusan Perikanan Fakultas Perikanan dan Ilmu Kelautan, Universitas Diponegoro. $80 \mathrm{hlm}$.

Tangke U, Karuwal JC, Zainuddin M, Mallawa A. 2015. Sebaran suhu permukaan laut dan klorofil-a pengaruhnya terhadap hasil tangkapan yellowfin tuna (Thunnus albacares) di Perairan Laut Halmahera bagian selatan. J IPTEKS PSP. 2:248-260.

Wallpole RE. 1995. Pengantar Statistika. Sumantri B, penerjemah. Jakarta: PT Gramedia Pustaka Utama. 